\title{
SPATIAL ANALYSIS OF EROSIVE PROCESSES IN PLATEAUS AND DEPRESSIONS OF THE UPPER PARAGUAI RIVER BASIN
}

\author{
Daniel Dias de ANDRADE ${ }^{1}$ \\ João dos Santos Vila da SILVA2 \\ Vera Aparecida FIGUEIREDO3 \\ Elisa Calhau de CASTRO ${ }^{4}$
}

\begin{abstract}
Natural characteristics may contribute to the erosion of the soil and to environmental imbalances, and in most cases, they initiate the imbalances that will be exacerbated by human activities. The presence of asymmetry in a frequency diagram is a valuable fact, and may indicate irregularity in the occurrence of events or aggregation of events in preferred locations. Thus, this work aims to demonstrate the use of Geographic Information Systems (GIS) of statistical analysis based on patterns of frequency, density, distribution and spatial dependence of sample points through a cutout of the mapping of the geotechnical aspects conducted for the State of Mato Grosso, generated for the entire area of plateaus and depressions of the Upper Paraguai river basin and its internal units of drainage basins. In most cutouts used in the analysis, the values indicated that is void the possibility that the distribution patterns of erosive events were resulted of chance. The aggregate pattern shown may tend to attract new points, facilitating the transmission of the sample's qualities through these, favored by your proximity and by the characteristics of the occurrence area.
\end{abstract}

Key words: Pantanal. Erosion processes. Patterns of points. Distance.

\footnotetext{
1 Mestre em Geografia. Rua Francisco Pereira Coutinho,490. Parque Taquaral. Campinas - SP. CEP 13087-120. E-mail: diasandrade.daniel@gmail.com

2 Pesquisador A. Embrapa Informática Agropecuária. Avenida André Tosello, 209. Cidade Universitária. Campinas - SP. CEP 13083-886. E-mail: joão.vila@embrapa.br

3 Bolsista DTI. Embrapa Informática Agropecuária. Avenida Dr. Bernardo Kaplan, 14 apto 84. Parque Brasília. Campinas - SP. CEP 13091-410. E-mail: vera.aparecida@gmail.com

4 Mestranda em Eng. Elétrica. Rua Major Solon, 311 apto 43. Cambuí. Campinas - SP. CEP 13024091. E-mail: ecalhau@gmail.com
} 


\section{Resumo}

\section{Análise espacial dos processos erosivos nos planaltos e depressões da bacia hidrográfica do Alto Paraguai}

Características naturais podem contribuir para a erosão do solo e para os desequilíbrios ambientais, e na maioria das vezes iniciam os desequilíbrios que serão agravados pelas atividades humanas. A presença de assimetria no diagrama de frequência de uma variável é um fato valioso, e pode indicar irregularidade na ocorrência de eventos ou agregação de eventos em locais preferenciais. Este trabalho tem o objetivo de demonstrar o uso em Sistemas de Informações Geográficas (SIG) de análises estatísticas baseadas em padrões de frequência, densidade, distribuição e dependência espacial das amostras pontuais de ocorrências erosivas, por meio de um recorte do mapeamento dos aspectos geotécnicos realizado para o Estado do Mato Grosso, geradas para toda a área de planaltos e depressões da bacia do Alto Paraguai e para as suas unidades internas de bacias de drenagem. Na grande maioria dos recortes utilizados na análise, os valores indicaram que é nula a possibilidade de que os padrões de distribuição das ocorrências erosivas tenham sido resultado do acaso. O padrão agregado apresentado pode tender a atrair novos pontos, facilitando o aparecimento e a transmissão das qualidades das amostras entre si, favorecidos pela proximidade e pelas características da área em que ocorrem.

Palavras-chave: Pantanal. Processos erosivos. Padrões de pontos. Distância.

\section{INTRODUCTION}

In the category of a large and relatively complex dune-alluvial coalescence plain, sediment transport to the Pantanal in Mato Grosso State from the highest parts of the Upper Paraguai River Basin is not a modern phenomenon and has been studied based on perspectives related to the most remote periods of the formation of the basin.

According to Ab'Saber (2006), in the study of the Quaternary of the Pantanal in Mato Grosso, there are important documents such as "the presence of a limestone formation, derived from the concentration of carbonates removed from very old limestone rock, under climatic and pedogenesis semi-arid conditions" (Xaréis Formation), and "significant occurrences of stone lines in areas as far apart as the hills of Cuiabá and the slopes of Urucum massif", added to the gigantic sandy alluvial fans formed by all quadrants of the Pantanal depression" (except their western side)

The post-Pleistocene climatic humidification would have altered the transported materials, with gradually thinner materials, however, it did not have the strength to cancel the participation of sandy and silica debris, and pro-part argillaceous already massively deposited from the foothills of structural escarpment with drainage obsequious, becoming reworked. Large masses of these sands inherited from the previous climatic phase have been accumulated in marginal dykes of the meandering plains over the past millennia (AB'SABER, 2006).

This sectorized humidification of the great Pantanal depression favored the expansion of ecosystems of Cerrado, Cerrado fields, Cerradões and the Chaco, as well as biotic compounds from the dry northeast and the periamazonic region. From the dissection of the Cuiabano pediplane to the formation of the Pantanal basin, after the last crisis of dryness of the Late Pleistocene, there was a reconquest by different stocks of tropical vegetation from refuges and cantonment redoubts in plateaus, 
escarpment ranges and adjacent firm lands. On the northern side of the Upper Paraguai Basin, in the area of the plateaus, depressions and surrounding escarpments, masses of periamazonic vegetation entered and adapted to live with the current conditions of the northern sectors of the Pantanal in Mato Grosso (AB'SÁBER, 2006).

As for the allochthonous rivers in the Pantanal, these have another hydrogeochemical composition, and they are added to the typical conditions of the Pantanal lands. The rivers that reach the Pantanal are the ones that most bring pollution loads to the plains, due to their transit through agricultural areas, which are consolidated and expanding and release pesticides and fertilizers during the water season. Also according to Ab'Sáber:

The Pantanal continues to receive the pesticide syrup from the properties located in the headwaters of the drainage that, until very recently, fed their lands only with natural waterways, that is, hydrogeochemically natural. Now the poisonous products come from afar, participating in some way in the floods of its waters, through the corixos, lagoons and bays. Residues of accelerated erosion are included in the "trade" of river sedimentation in immense sections of the Pantanal rivers, and an unexpected modification begins in the millennial sedimentation processes (AB'SABER, 2006, p.14).

Natural characteristics can contribute to potential erosion of slopes and environmental imbalances in river basins, and most of the time, these factors initiate imbalances that will be exacerbated by human activities. Internally, from the point of view of self-adjustment, due to changes in energy input and output, the river basins integrate joint view of the behavior of natural conditions and human activities developed there, and are excellent study areas for the planning (GUERRA; CUNHA, 1996)

Erosive features resulting from endogenous and exogenous surface processes are often related to changes in the type of land use and cover, representing the mark left by lack of planning and misuse of natural resources and territory, often due to lack of knowledge of the environment and short-term political and economic pressures.

According to the Methodological Guidelines for Ecological-Economic Zones (ZEE) of Brazil, the diagnosis of the biotic-physical environment should range from collecting to analyze hydrological, climatological, geological, geomorphological, pedological and biodiversity data, and should result in the identification of environmental units from the detection of integrity of natural systems, with their potentialities and limitations, based on the principles of sustainable development. However, the Brazilian ZEE is in various stages of implementation and execution, requiring technical, financial and institutional support.

In this perspective, specifically for the ZEE previously approved for the study area of this work, in the State of Mato Grosso,, this is not based on a prognosis that can guide the future uses of the territory, and makes it impossible to define the intensities of anthropic intervention (MMA, 2012)

Based on the spatial analysis aimed at the detection of areas of higher occurrence and areas susceptible to the occurrence of the erosive processes, considering the type of land use, relief and soil formation that cover each one of the basin units of the plateaus and depressions of the Upper Paraguai river basin, it is possible to attribute some main characteristics that would facilitate the formation of erosional processes regionally, and thus, to plan policies to mitigate these processes.

The presence of asymmetry in the frequency diagram of a variable is a valuable fact and may indicate irregularity in the occurrence of events or aggregation of events in preferred locations, among others. This property indicates that there is a spatial 
differentiation between the geographical units sampled, since most of the values do not tend to a central value, and the values near the mean do not necessarily have a higher distribution occurrence. Thus, unlike the Normal probability density function, the Poisson function is asymmetric and can show spatial location influences on the values of a geographic variable (FERREIRA, 2014)

The Normal probability function is more suitable to the continuous random variables, in turn the Poisson function, or Poisson distribution, to the discrete random variables, since the probability of occurrence of these events is low, are able to describe frequencies of occurrence of events in units of regular area, as well as the real distribution of the number of these phenomena, as well as to evaluate the spatial distribution of the objects from the frequency of these by space unit (CLARK; HOSKING, 1986; ANDERSEN, 1980 apud FERREIRA, 2014).

As an alternative, the Kernel density map can be used to analyze pattern behavior, highlighting the point intensity of a given phenomenon throughout the study region, facilitating the visualization of conglomerates. The visual analysis can be impaired when there is a great concentration of points in the same place, occurring that a point can actually present a greater number of occurrences.

Another technique used for the comparison of spatial patterns in point maps is the analysis of the frequency distribution of points per squares samples. In this technique, each square is an area unit where a certain amount of events occur, representing a discrete random variable that tends to be distributed according to the Poisson function, and the parameter that indicates if the spatial pattern of the points on the map is more aggregate, random or scattered is the ratio " $r$ " between the variance $\left(\sigma^{2}\right)$ and the mean $(\lambda)$ of the number of points per square (FERREIRA, 2014) (equation 1). The variance will be less than the average if the arrangement of the points has a more regular distribution pattern than random, however, if the point arrangement is more aggregate than random, the variance will be greater than the mean (MCCONNEL; HORN, 1972 apud FERREIRA, 2014).

$$
r=\sigma^{2} / 1
$$

In order to reproduce the spatial variability of a surface through representations of the random function model, it is necessary to define the hypothesis that the stochastic process is second order stationary, that is, a process which the mean is constant in space and which the covariance depends only on the vector distance between the samples, or of the neighborhood structure between them (CAMARA; CARVALHO, 2014)

The measure of the length of the shortest line between two points in a cartographic plane, or measure of distance between points, is known as the Euclidean distance. The use of Euclidean distance almost entirely disregards the altitude variation between neighboring positions (produced by the millenarian interaction between geological, atmospheric and anthropic factors), the arrangement of geographic objects, the complexity of networks and routes, the fluidity of the territory, among other associated spatial properties that give unity to the local landscape and the built space.

Thus, the greater the difference between the real measure of distance between objects, subject to impedances or frictions to motion, in relation to the Euclidean measure, which allows the absolute addressing of the geographical fact, but not necessarily of its spatial interaction, the greater will be the impedance to the movement between two or more localities (FERREIRA, 2014)

For the analysis of the different degrees of spatial organization and spatial dependence of the point process, one of the most used techniques is the Euclidean Distance to the Nearest Neighbor. According to Taylor (1977), for any analysis of the 
nearest neighbor, we have an Observed Average Distance, or real average $\left(r_{a}\right)$, and we can calculate an Expected Average Distance $\left(r_{\mathrm{e}}\right)$ under random expectations. The divergence between the actual pattern of point distribution and randomness can be expressed as a simple " $\mathrm{R}$ " ratio (equation 2 ):

$$
R=r_{a} / r_{e}
$$

The score " 0 " for this index represents a situation in which the mean distance is null, and there is the limit case of a pooled pattern. When $R=1$, the observed average distance is the expected average distance, and so, on average, a random pattern is indicated. Higher scores represent varying degrees of dispersion. The score " 2 " is the result of a regular quadratic pattern, and $\mathrm{R}=2.149$ resulting from a regular pattern limited in a triangular structure. In practice, empirical examples of point distribution patterns result in some value between $R=0.33$ and 1.67 (TAYLOR, 1977)

In addition, rarefied spatial data available only for some points of the cartographic plane can be used by combining algebraic (original values) and geometric (distance) elements in the construction of surfaces by interpolating the irregular spaced data. The result of this interpolation is the Isodistance Surface, which represents, between the interval of two isolines of Euclidian distance, the degree of relative spacing between a cell located in this range and the nearest object, assigning a place or object a value that differs from the others due to their immediate neighborhood. Thus, we can compare two or more spatial distributions of the distances calculated on two or more maps (FERREIRA, 2014).

Also, Ferreira (1999) showed that the standard deviation $(\sigma)$ of the distances of each map is the best between position and dispersion parameters to compare two or more Isodistance Surfaces. According to the author, standard deviation and distances have inversely proportional relations between them, being that "the more distant the reference objects are between them (the less the degree of neighborhood of the surface), the smaller the standard deviation of the distances between them".

\section{OBJECTIVE}

Performing spatial analysis based on frequency, density, distribution and distance patterns in geotechnical samples for the area of the plateaus and depressions of the Upper Paraguai river basin, in the State of Mato Grosso, and for the boundaries of the sub-basins selected in the same area.

\section{MATERIALS AND METHODS}

The project "Uniformization of the ecological and economic zoning of the Legal Amazon and integration with agroecological's zonings in the region" has as one of the objectives the availability of a WebGIS i3Geo (MMA, 2014) platform called "Interactive Geospatial Analysis System of the Legal Amazon" - Siageo Amazônia (SIAGEO AMAZÔNIA, 2016), of the various mappings derived from the technical studies that compose the Ecological-Economic Zones of the nine states that integrate the Legal Amazon. 
In this context, the preliminary punctual mapping of the furrows, ravines and voçorocas samples from Siageo Amazônia is included within the Physical Environment division, in a theme called "geotechnical aspects"

On the occasion of the 6th Symposium on Geotechnology in the Pantanal (GeoPantanal), in Cuiabá, Brazil, in October 2016, one of the mapped points was visited, attributed to a formation of ravines, distant in about 400 meters to the west of the originally indicated position, next to a large area of soybean plantation on the fringes of tablelands that mark the limit between the municipalities of Cuiabá and Chapada dos Guimarães. Apparently, the erosive feature was controlled with seedings in the ravine areas, combined with the preservation of the vegetation cover of the valleys below (Figure 1).

In agreement with the areas of greatest contribution of sediments and pollutant loads to the Pantanal plains, it was delimited for this work the area of the plateaus and depressions of the northern part of the Upper Paraguai basin, derived from the boundaries of the Paraguai river basin (SILVA; ABDON, 1998) in the State of Mato Grosso, subtracting the Pantanal plain area.

The total area of the polygon used for the analysis is approximately 125 thousand square kilometers, and the punctual samples of the erosive processes cut from this area cover a grid of Minimum Longitude and Latitude of -58.8458 e -17.9597 and Longitude and Latitude maximums of -53.3433 and -14.181 , in decimal degrees, and they account for 136 sample points.

The frequency distribution of points per squares samples method was performed on the Quantum GIS (QGIS, 2016), version 2.12.3 Lyon, generating a regular grid with 10 kilometers side, or 100 square kilometers area, and through the Tool "points in the polygon", the frequencies were counted.

The calculation of the Kernel map produced to delineate the "heat areas" with the highest point intensity of samples was produced from the "Heat Maps" complement, also from the QGIS, for the entire study area. A radius of 20,000 meters, equivalent to the sum of the sides of two sample squares used in the previous method, was indicated for the analysis, and the Kernel estimation function type indicated for quartic (twopart function).

The width of the influence radius on the Kernel maps determines the degree of surface smoothing and defines the samples that will be used to estimate the value at a non-sampled point. The estimation function counts the events across the distance and according to the region of interest, representing a surface with a value proportional to the intensity of the events per unit area. Subsequently, the areas that presented values indicative of the presence of two or more samples present in a radius of 20 kilometers from each cell (pixel) were vectorized.

The Isodistance Surface Analysis was performed on the ArcGIS Geographic Information System (ESRI, 2008), version 9.3, from the spatial analysis module and the "Euclidean Distance" function. The function converts the samples points into ranges of values (isolines) of the Euclidean distances, measured from one point to the next, in any direction, according to standard deviation intervals with respect to the mean of these distances.

Isodistance surfaces were generated for the entire area of the plateaus and depressions of the Upper Paraguai basin and for the individually selected sub-basins, containing cells representing the range of Euclidean distance values of each point from the nearest point (ArcGIS Desktop version 9.3 Help)

Figure 1 shows the result of the number of occurrences per grid accounted for the entire study area, and the areas delimited by the Kernel density analysis and the isodistances between the samples, considering the entire area of the plateaus and depressions of the Upper Paraguai river basin. 


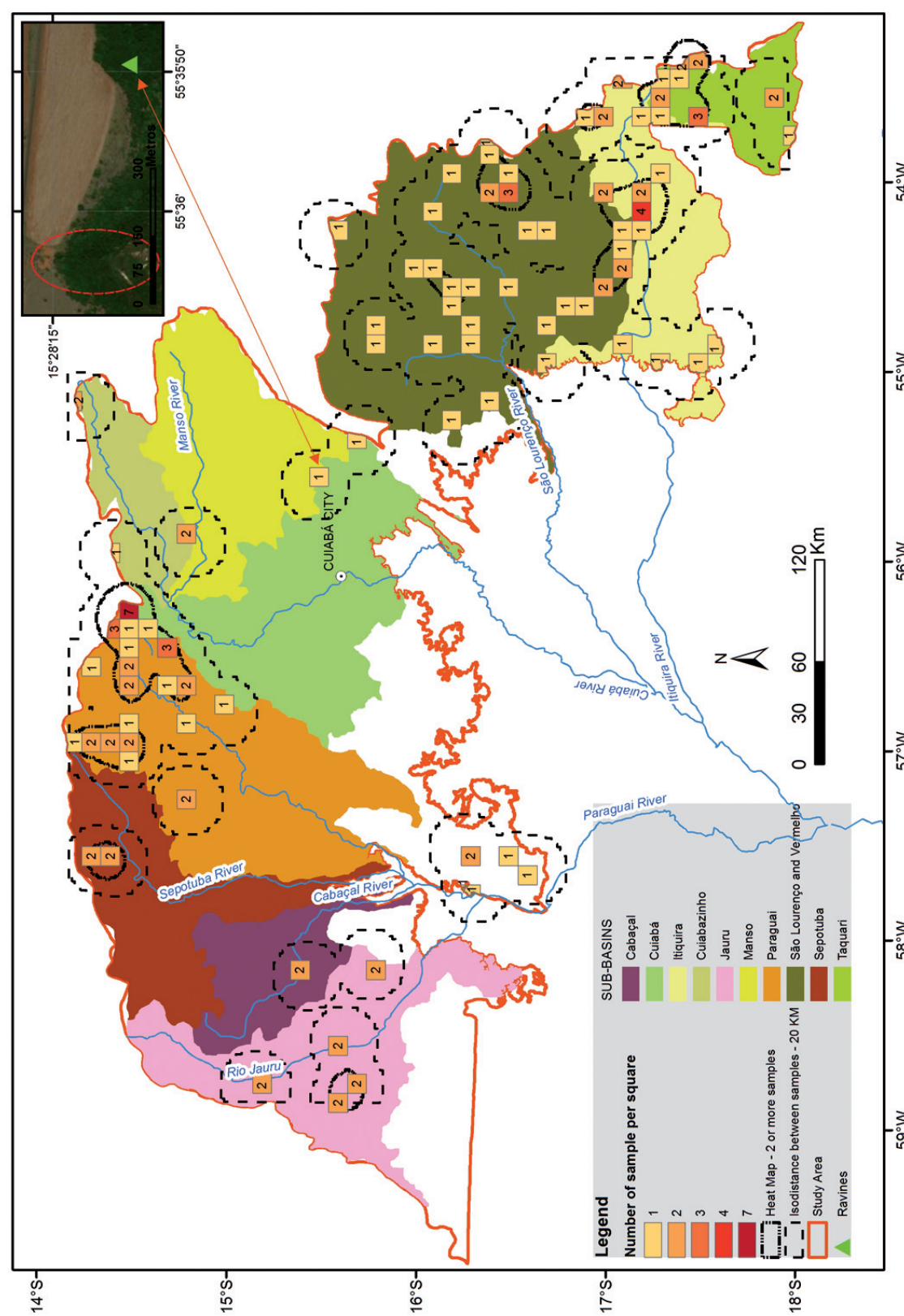

サ ช U U

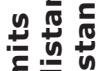
른 응 ดे >

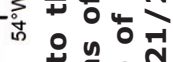
눈 రृ 웅도 을돈 돈 3 '든 동 언 윽 은 는 ดे yे ตำ 은 는든 ำ ถู

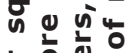
3 ᄂ 인 을 ษ ด 느을 응 은 ด온 인은 U 3 는뽕응 $03 \div-\frac{8}{6}$ $\geq n \overline{0}$ "ท 인 닌 ᄂ ○ U ง $\frac{1}{1}$ 언른 든넌 는 넌 نㄴㄴㄴㄷㄴ 은 든 4 3 ᄂ 今 로온 ํㅗㅎ - 1 ह 드릉 인 
Subsequentlly, the statistics of the mean $(\lambda)$ and variance $\left(\sigma^{2}\right)$ of the number of occurrences between the squares were calculated for the entire study area and separately for the cutouts of the selected basins.

For the analysis of the boundaries of the sub-basins selected, from the division of Ottobacias of level 4, made available by the National Water Agency (ANA, 2016), named in agreement with the names of the main rivers of the hydrographic network in $1: 250,000$ scale, also made available by the same agency, the points of the samples inserted within each basin were cut out, totaling 124 occurrences, and it was also applied the statistical methods of frequency distribution of points per squares samples and Euclidean Distance to the Nearest Neighbor. The Drainage basin of the Cabaçal river, between the Cuiabá and Cuiabazinho river basins, were excluded from this stage because they had only 2 samples (furrows and ravines) and 1 sample (ravines), respectively.

The analysis of the Euclidean Distance to the Nearest Neighbor was also performed in the QGIS. The function returns the Observed Average Distance $\left(r_{a}\right)$, Expected Average Distance $\left(r_{e}\right)$, Nearest Neighbor Index $(R)$, and Z-cut. The Z-cut values allow us to infer if the observed differences are statistically significant, and extreme values allow us to reject the null hypothesis that the observed patterns may be the result of chance.

\section{RESULTS AND DISCUSSION}

The presence of asymmetry in the histogram of the data may indicate that the event does not follow a normal distribution of points, but rather a distortion, which indicates locational dependence of the events, following the Poisson precepts.

The figure 2 shows the number of squares inserted in the limits of each basin selected for the study, next to the number of samples present within these limits, and, finally, the percentage of squares containing at least one sample of erosive feature, indicating the irregularity and the heterogeneity of the distribution of the samples throughout the study area.

In the area between the limits of the regular grid that was cut for entire area of the plateaus and depressions of the northern strip of the Upper Paraguai basin, the average would be 136 points / 124,903 $\mathrm{Km}^{2}$, in case the distribution of the points was random. However, observing the values counted in the basins of Figure 1, the number of observed points would be very different from one expected, clearly showing a distortion in their distribution.

Based on the values of the variance and the mean for the spatial distribution of points, the ratio " $r$ " (equation 1 ) was calculated, statistically confirming this trend. For the entire study area, we have variance $\sigma^{2}=0.206$ and mean $\lambda=0.108$; therefore, the ratio will be equal to 1.899 , indicating an aggregate distribution pattern of occurrences (cluster).

In the analysis of Euclidean Distance to Nearest Neighbor, the points had the mean distances to their neighbors calculated, and compared to a hypothetical random point distribution, considering the same number of points covering the same total area (equation 2). The analysis done for the entire study area returned the cutoff values of " $Z$ " of -14.749 and "R" of 0.339 (fairly aggregate). 


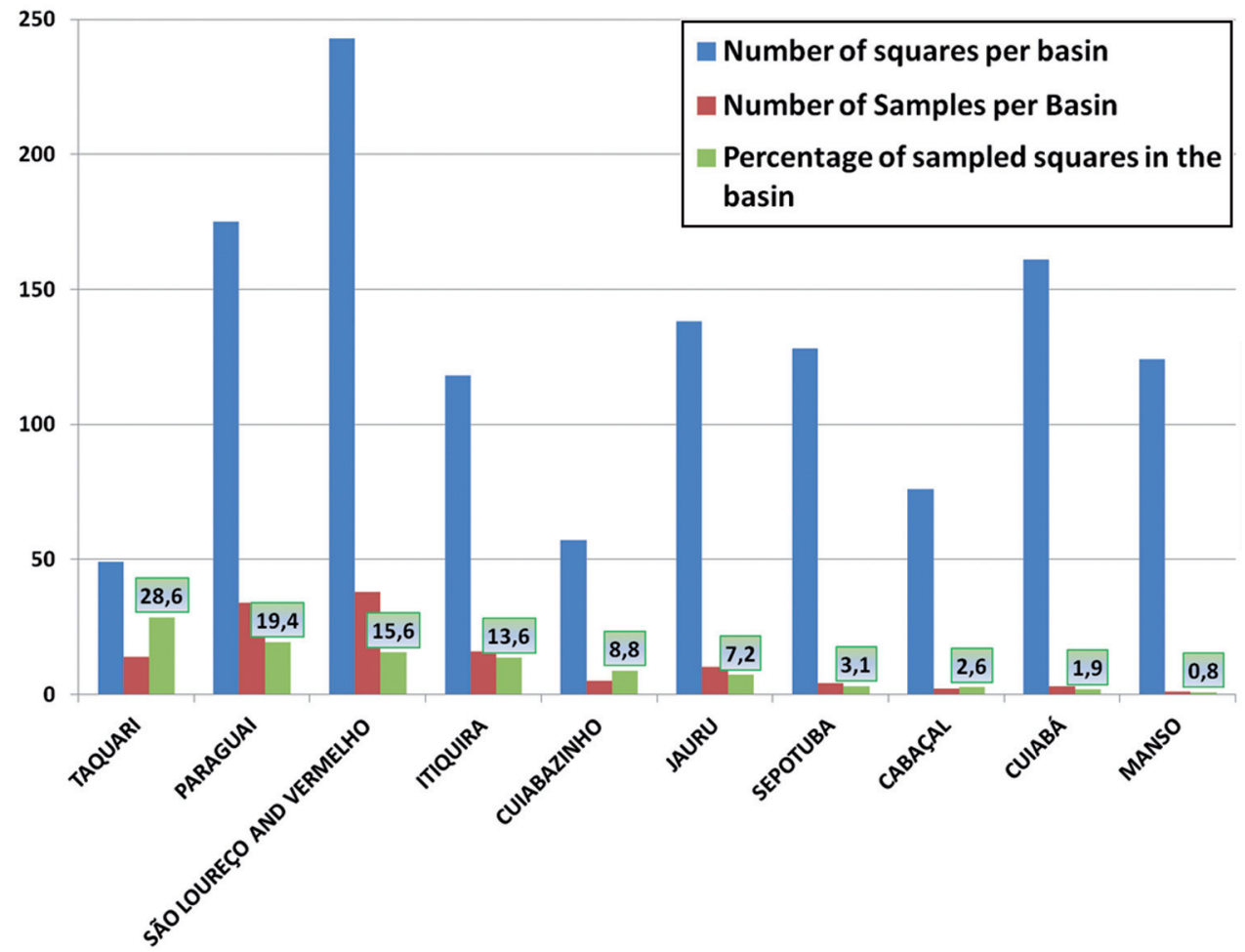

Figure 2 - Histogram of occurrence of squares and samples by Drainage Basin

The Isodistance Surface generated for the entire study area, converting the sample points into isolines according to standard deviation intervals in relation to the mean of the distances, obtained the final value of its standard deviation of around 42.5 kilometers, much higher than the ones obtained in the individual analyzes by basin (table 1), also indicating a high degree of neighborhood between the reference objects.

From the analyzes that consider the boundaries of the dividers of the subbasins individually selected, Table 1 presents the number of samples per basin $(\mathrm{N})$, the variance values $\left(\sigma^{2}\right)$, the mean $(\lambda)$, and the frequency of points per square $(r)$; the values of Observed Average Distance $\left(r_{a}\right)$, Expected Average Distance $\left(r_{e}\right)$, Nearest Neighbor Index (R) and Z-cut $(Z)$ for the Euclidean Distance to the Nearest Neighbor Analysis, and the values of the Standard Deviation $(\sigma)$ in relation to the average of the Euclidean distances calculated for the analysis of Isodistance Surfaces. 


\section{Table 1 - Number of samples per basin $(N)$, variance values $\left(\sigma^{2}\right)$, mean \\ $(\lambda)$, and the ratio $(r)$ of frequency distribution of points per square; values of Observed Average Distance $\left(r_{a}\right)$, Expected Average \\ Distance $\left(r_{e}\right)$, Nearest Neighbor Index $(R)$ and the Z-cut $(Z)$; \\ and the values of the Standard Deviation $(\sigma)$ in relation to the average of the Euclidean distances calculated}

\begin{tabular}{cccccccccc} 
& $\mathrm{N}$ & $\sigma^{2}$ & $\lambda$ & $r$ & $\mathrm{r}_{\mathrm{a}}$ & $\mathrm{r}_{\mathrm{e}}$ & $\mathrm{R}$ & $\mathrm{Z}$ & $\sigma$ \\
\hline JAURU & 10 & 0.14 & 0.072 & 1.927 & 0.003 & 0.105 & 0.028 & -5.882 & 13.835 \\
SEPOTUBA & 4 & 0.061 & 0.031 & 1.969 & 0.004 & 0.01 & 0.393 & -2.322 & 1.052 \\
PARAGUAI & 34 & 0.419 & 0.194 & 2.159 & 0.052 & 0.078 & 0.663 & -3.756 & 7.44 \\
CUIABÁ & 3 & 0.031 & 0.019 & 1.648 & 0.039 & 0.023 & 1.7 & -2.32 & 1.755 \\
CUIABAZINHO & 5 & 0.15 & 0.088 & 1.712 & 0.086 & 0.151 & 0.57 & -1.84 & 14.041 \\
SÃO LOURENÇO & 38 & 0.189 & 0.156 & 1.212 & 0.109 & 0.126 & 0.862 & -1.636 & 12.634 \\
AND VERMELHO & & & & & & & & & \\
ITIQUIRA & 16 & 0.27 & 0.136 & 1.989 & 0.089 & 0.122 & 0.730 & -2.063 & 10.384 \\
TAQUARI & 14 & 0.449 & 0.286 & 1.571 & 0.042 & 0.07 & 0.611 & -2.784 & 6.281 \\
\hline
\end{tabular}

In all cases, the presented values of variance were higher than the values of the frequency means of the number of points per square sample, resulting in an occurrence frequency pattern $(r)$ closer to the aggregate than to the random one. Within this scenario, it is possible to infer that higher values of $r$ represent the presence of areas of greater susceptibility to the occurrence of erosive features, where these are more aggregated in some sectors of the geographic space (drainage basin).

In the case of occurrences of erosive processes, values of $\mathrm{R}$ close to the minimum limit of the aggregate standard (cluster) according to Taylor (1977), presented by the Jauru, Sepotuba, Paraguai, Cuiabazinho and Taquari river basins, represent the cases of greatest concern, based on the concentrated pattern of distribution between the features.

Cut-off values $(Z)$ of less than -2.58 and greater than 2.58 have a probability less than $1 \%$ that the pooled scatter distribution patterns may have resulted from chance (ArcGIS Desktop version $9.3 \mathrm{Help}$ ). Thus, there is a probability of less than $1 \%$ in the Euclidean Distances to the Nearest Neighbor analyses for all the area of the plateaus and depressions of the northern range of the Upper Paraguai basin, and individually for the basins of the Jauru, Paraguai and Taquari rivers, that the observed patterns may be the result of a random distribution of erosive events. Also, in the distribution patterns observed in the Sepotuba, Cuiabá and Itiquira river basins, there is a $5 \%$ probability that these may have resulted from chance. In the basins of the Cuiabazinho and São Lourenço and Vermelho rivers, this probability is $10 \%$.

In the case of the Jauru river basin, the analyzes confirm a concentration of occurrences that would be impossible in a visual analysis of distribution patterns. By presenting 10 samples concentrated in 5 zones of occurrences, it can be concluded that the lower value of " $R$ " presented (smaller real mean distances measured), the 
curve represented in the Heat Map and the high value of the standard deviation resulting from the map of Isodistances Surface statistically indicate regions more vulnerable to the occurrence of erosive processes within the limits of the basin.

The basin of the São Lourenço and Vermelho rivers, with 38 samples, presented the value of the " $\mathrm{R}$ " index closest to the randomness, and the lowest " $r$ " value, indicating the smallest difference between variance and mean number of occurrences per square.

In the Cuiabá river basin, where the pattern of occurrence distribution was dispersed, this occurred in the presence of a smaller number of samples compared to the other basins, in a basin that comprehends 4 municipalities and partially other 4, the three existing samples being concentrated at the most extreme north point of its limits, southeast of the municipality of Diamantino. If a further cut for the analysis was considered, the samples in question would be in a region with a high concentration of occurrences, next to the square with the highest number of occurrence (5), in the Paraguai river basin, also in Diamantino.

Results such as the one mentioned may have influenced in part, as Unwin (1981) warns, by edge effects introduced in studies where the pattern of mapped points merely represents a "window", placed on a real-world pattern. Points near the boundaries of the map are forced to find neighbors within the mapped area, while in the real world the closest neighbors may be outside the area of analysis.

Additionally, assuming that Euclidean geometry is appropriate in certain analyses may cause some problems. In practice, reproductions of empirical patterns are many, and the resulting patterns are much more complex than the simple limit case at each end of the R scale. Even when the dominant process is contagious or competitive, it does not consider possible real-space impedances, and the resulting pattern may tend only toward a boundary position along the R scale (TAYLOR, 1977).

As for random patterns, this usually indicates a distribution and a density different from the patterns of geographical distributions, which spatial differences and discontinuities are also due to the factor distance, access and spatial dependence between the objects, influenced by the relief, by the land division and land use, the presence of transport systems and services, etc.

Within a dispersed distribution pattern, preexisting points tend to repel new points, while in the aggregate pattern, preexisting points tend to attract new points. This last process is called spatial contagion, and facilitates the transmission of attributes between two or more objects, since it is favored by the proximity between them (FERREIRA, 2014).

In a random pattern, the location of the points does not show to be influenced by their attributes, such as the physical properties of formation of a soil type more susceptible to erosion processes. In terms of use, conservation and planning for the region of study, the identification of regions susceptible to the formation and concentration of erosive processes is an important variable to be aggregated in future analyzes and interventions.

The emergence of erosive features have their genesis in natural and anthropic factors, the latter characterized mainly by changes in land use and occupation. The opening and construction of roads can represent an important fact in the emergence of these processes, however, it may represent an inaccuracy in the conclusion of the analysis performed for this work, because when the roadmap is superimposed on the existing samples mapping, most of these are located close to the routes, and should be considered the possibility of non-sampling in restricted areas.

It should also be considered that for this study, relative weights were not established for the different erosive features (variable values), namely furrows, ravines and voçorocas, different in their formation and impact on the environment. It should 
also be noted that the spatial analyzes performed are necessarily associated with the original scale of the mapping performed and the spatial resolution of the input data, and that a different scale and resolution may reveal other spatial patterns.

Considering the particularities described above, the value of " $\mathrm{R}$ " indicates that there is no possibility that the spatial patterns observed in the analyzed basins reflect the hypothetical random pattern represented by their null hypotheses. Therefore, the hypothesis $\mathrm{H}_{0}$ is rejected for these analyzes.

\section{CONCLUSION E SUGGESTIONS}

Considering the purpose of applying statistical analysis in Geographical Information Systems based on frequency, density, distribution and distance between points, the study obtained positive results of the execution.

The continuity of the performed analyzes with the realization of a new survey of the geotechnical aspects to the study area, within the context of the new State EcologicalEconomic Zoning, will be fundamental in the determination of the processes of spatial contagion and temporal and evolutionary analysis of the erosive processes, constituting an important product to be used in more specific actions of the policies of prevention and mitigation of the erosive processes in the soils of the region.

\section{REFERENCES}

AB'SABER, A. N. Brasil: paisagens de exceção: o litoral e o Pantanal Matogrossense: patrimônios básicos. Cotia, SP: Ateliê Editorial, 2006. 182 p.

ANA. Agência Nacional de Águas. Áreas de contribuição dos trechos da rede hidrográfica codificadas segundo o métodos de Otto Pfafstetter para classificação de bacias. Disponível em: <http://www.ana.gov.br/bibliotecavirtual/ solicitacaoBaseDados.asp> Acesso em 30 de junho de 2016

CÂMARA, G.; CARVALHO, M. Analise Espacial de Eventos. In: FUCKS, S.; CARVALHO, M. S.; CÂMARA, G.; MONTEIRO, A. M. (Org.). Analise Espacial de Dados Geográficos. Brasília: Embrapa, 2004. p. 55-78.

ESRI. ArcGIS Desktop: Versão 9.3. Redlands, CA, 2008. 1 CD-ROM

FERREIRA, M. C. Iniciação à análise geoespacial: teoria, técnicas e exemplos para geoprocessamento. São Paulo: Editora Unesp, 2014. 343 p.

GUERRA, A. J. T.; CUNHA, S. B. da (Org.). Geomorfologia e meio ambiente. Rio de Janeiro: Bertrand Brasil, 1996. 372 p.

MMA. Ministério do meio Ambiente. Interface Integrada para Internet de Ferramentas de Geoprocessamento - I3Geo, versão 5.0 SP3. Disponível em <http:/ /mapas.mma.gov.br/i3geo> Acesso em: 22 de Outubro de 2014.

MMA. Ministério do Meio Ambiente. Nota Técnica n 10/2012 - DZT/SEDR/MMA, 23 de março de 2012. 
QGIS Equipe de desenvolvimento, 2016. QGIS Sistema de Informações Geográficas. Open Source Geospatial Foundation Project. Disponível em <http:// www.qgis.org> Acesso em 21 de janeiro de 2016.

Siageo Amazônia. Sistema Interativo de Análise Espacial da Amazônia Legal. Disponível em: <http://www.amazonia.cnptia.embrapa.br/> Acesso em 05 de julho de 2016.

SILVA, J. dos S. Vila da; ABDON, Myrian de Moura. Delimitação do Pantanal Brasileiro e suas sub-regiões. Pesquisa Agropecuária, Brasília, v. 33, Número Especial, p. 1703-1711, 1998.

TAYLOR, P. The spacing approach. In: TAYLOR, P.J. Quantitative methods in geography. Boston: Houghton Mifflin Co., 1977. p. 156-174.

UNWIN, D. Introductory spatial analysis. London: Methuen, 1981. 